\title{
Secondary Publications in Education: A Study of Duplication
}

\begin{abstract}
Duplication of coverage is examined to give librarians a closer acquaintance with three indexes found in education-psychology libraries. Two educational indexes overlap of coverage is studied in terms of editorial policy, growth and size of coverage, cover-to-cover vs. selective indexing, and the subject orientation of the periodicals concerned in order to compare two approaches to the same discipline. One index in psychology is contrasted to the two in education, but the main focus is on the mutual interests of these two disciplines.
\end{abstract}

$\mathbf{T}$ oxtent do these indexes duplicate each other? I seem to see the same articles listed." In an educationpsychology library the user was referring to Education Index, ERIC's Current Index to Journals in Education, and Psychological Abstracts. Naturally, the two educational indexes would duplicate each other but to what degree and how do they differ? Are the mutual interests of education and psychology centered solely on educational psychology, or do they coincide in other areas? And what are those "other areas"? That is, what are the periodicals and what are the fields supporting these two disciplines that they represent.

To answer these questions this study examines duplication of coverage and interests between these indexing services and sketches a profile of the subject orientation of the periodicals within each service. Hopefully, the resulting picture will provide librarians with a better "feel" for the indexes which will prove useful when guiding the user.

Lawrence J. Perk is an information specialist, Mechanized Information Center, Ohio State University Libraries, Columbus.

\section{METHODOLOGY}

Data organization required a master list of those periodicals indexed, noting (a) which index covered a title, (b) whether the indexing was cover-to-cover or selective, and (c) the subject orientation of the publication according to periodical and serial directories, ${ }^{1-3}$ or estimation based on the title. Totals were simply extracted from this list.

The data are based on one point in time, December 1974. But the indexes had grown considerably in the five preceding years. This growth should be kept in mind when users are scanning more than the latest issues. Figure 1 shows that CIJE (Current Index to Journals in Education) had doubled its coverage since its inception in 1969, and PA (Psychological Abstracts) had expanded half again as much in the same period. The time up to $1971-72$ was one of rapid growth for both but has since tapered off. In contrast, the coverage of EI (Education Index) was one of relative non-growth, and, therefore, its data can be better extended over time.

\section{Education}

There are five supporting elements in 


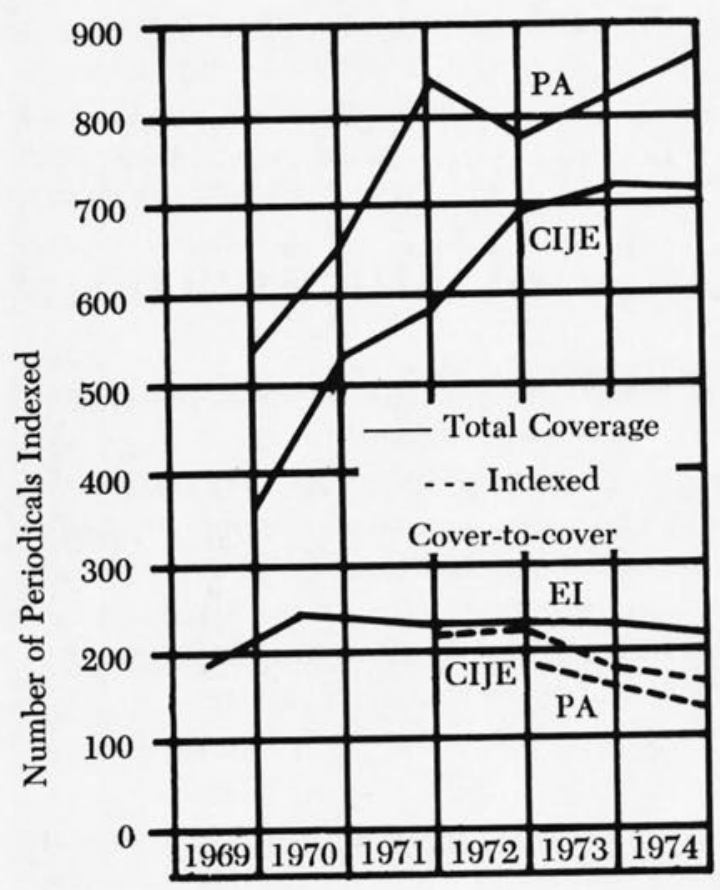

Figure 1

Growth of Coverage by Three Bibliographic Services: Education Index (EI), Current Index to Journals in Education (CIJE), and Psychological Abstracts (PA)

this study-namely, (1) editorial policy, (2) the overlap and non-overlap of coverage, (3) several indicators of the core titles, (4) the size of coverage, and (5) the subject nature of the above. All five are utilized in studying education where two indexes handling the same subject area can be compared.

\section{Editorial Policy}

A brief history can be helpful to identify those editorial decisions that have formed each index's particular characteristics.

Education Index (EI) of the Wilson Company has been the index in education from its inception in 1929 up to the appearance of CIJE in 1969. EI's selection policy is suggested by the Wilson Indexes Committee (ALA's Reference and Adult Services Division) which has combined periodic in-depth studies with subscriber vote since $1951 .{ }^{4,5}$ If this monitored-feedback system has been effective, the titles should represent a carefully tailored list of the most important journals in the field. However, it has responded only modestly to requests for greater coverage. And when doing so, it deleted personal author entries and certain types of materials from 1961 to 1969.6

Because of this limited coverage in $E I$ and the overall picture of secondary publications in education, the need was more forcefully stated for a new index that could provide better access to the vast amount of literature in the field, provide author entries, and supply some type of abstracting. ${ }^{7}$ As a result the Current Index to Journals in Education (CIJE) appeared in 1969 as part of the ERIC system. It, too, gathered subscriber information and appointed a panel, but this time the goals were less restricted resulting in the following comparisons.

\section{Overlap in Education}

When two independent services index the same literature, it could be expected that both would include the same titles. Actually, CIJE does duplicate 180 (83 percent) of $E I^{\prime}$ s 218 periodicals, indicating substantial agreement on the most useful titles. One difference then lies beyond this overlap of 180 . CIJE's coverage of 702 periodicals is more than three times that of $E I$, further illustrating its policy to assure "access to important articles published in periodicals which fall outside the scope of education-oriented literature."8 In contrast, EI prefers a non-growth coverage.

However, while CIJE expands deeply into noneducation-oriented literature, it bypasses thirty-eight periodicals or 17 percent of what EI considers relevant to education. Of these, twenty-eight are in education and, therefore, not merely alternatives for peripheral choices. (See Schorr for a list of the thirty-eight periodicals. $)^{9}$ 


\section{Core Periodicals}

Since both services want to include the major periodicals of the field, the core should exist in those chosen by both. However, since the peripheral literature can also overlap, a stronger indicator is whether a journal is fully indexed (cover-to-cover) or not. Fullindexing in this study is viewed as an editorial choice that infers total relevancy to the subject field. Full-indexing by several services is the ultimate indicator of the major journals.

$E I$ treats its entire coverage as a core collection. It indexes all 218 periodicals cover-to-cover, inferring that these choices are so relevant to education that every article in them should be accessible.

CIJE fully indexes 159 (23 percent), 101 of which overlap with $E I$. It is these 101 that we can call the hard core, since they are fully indexed by both services. Beyond this level of 101 lies the difference of treatment. CIJE continues with alternative choices for total indexing while preferring partial scanning for titles that EI considers worthy of full accessibility.

As noted before, CIJE overlaps 83 percent of EI. But the 101 figure of full-indexing overlap reduces that figure to 46 percent of EI. Therefore, while CIJE does duplicate most of EI's coverage, the type of indexing differs on half of the titles. EI includes those thirty-eight titles totally bypassed by CIJE.

These last features should be kept in mind if CIJE appears to subsume EI's coverage and usefulness. It should also be noted that numerous in-volume crossreferences, the use of subheadings/ sub-subheadings, and a time lag of only one to two months compared to CIJE's four to five months are some of the features that make $E I$ an easier index to use manually and preferable to certain users. ${ }^{10}$
On the other hand, Schorr has cast a doubt over the quality and depth of indexing in $E I$ as compared to that of CIJE. In his two examples, EI used only one and no subject descriptors while CIJE used close to its customary average of six per title. His article should be referred to for some additional comparisons including costs. ${ }^{11}$

\section{Psychology}

Compared to education, Psychological Abstracts (PA) fully indexes a smaller portion of its coverage, 138 or 16 percent of its 866. As with CIJE, PA relies heavily on an extensive periphery of 84 percent and Figure 1 reviews the somewhat similar pattern of rapid growth that expanded each coverage.

Of the total overlap, seventy ( 8 percent of $P A$ ) are surveyed by all three services, six of which are the fully-indexed hard core. If one considers any overlap with one or both of the other indexes, the total overlap increases to 160 (18 percent of $P A$ ), nineteen of which are fully indexed. Therefore, an ample number of periodicals are relevant to both disciplines. However, there is the possibility that one discipline borrowed totally from the other rather than there being a mutual interest in each other's field. This question reveals the weakness of pure overlap data alone. The following section tries to offset this factor by identifying the subject orientation of the periodicals involved.

\section{Subject Orientation}

Tables 1 and 2 are based on the subject assignments in periodical directories. Of the 1,436 periodicals in this study, 84 percent were listed in Ulrich's International Periodicals Directory, Irregular Serials and Annuals, or New Serial Titles; 13 percent had subjects added to those titles that seemed representative; and 3 percent were left without subject designations. Of those with subjects, 65 percent had single descrip- 
tors while each title averaged 1.4 descriptors.

There are pitfalls in reading the data because many titles belong to several subject categories. The categories cannot be added together without distortion. But in a very general way, one can scan the table and sense the emphases and balance of coverage within each index.

\section{Education}

The "Total" columns of Table 1 represent the total profile for each index in terms of the number of journals in that category and its percentage of the total journals covered in that index. One cannot add categories together, but one may judge a category's strength in relation to the whole and to that of other categories. An examination of Table 2 will give a picture of the number of periodicals that are unique to that index ("a" columns) and those that overlap others (columns b,c).
Comparison of the two education indexes shows somewhat parallel emphases and representation in each category. There is slightly more stress in CIJE on the periodicals in the social sciences, communication, linguistics, business, and the natural/physical sciences. These represent the major areas contributing to its peripheral growth. They are only minimally altered when education journals are removed as in the "T-Ed" columns, indicating those journals outside the field of education. EI consists mostly of educationally oriented titles but does have representation in almost every category.

\section{Psychology and Education}

Comparison of CIJE and PA reveals the wide range of interests shared by education and psychology. CIJE scans the periodicals more intensely in linguistics, communication, business, and the humanities, and PA depends heavily on

TABLE 1

Total Profile for Each Index by Subject Orientation of the Periodicals

\begin{tabular}{|c|c|c|c|c|c|c|c|c|c|}
\hline Subject & Total & $\underset{\%^{3}}{\text { EI }}$ & T-Ed ${ }^{1}$ & Total & $\mathrm{CIJE}^{4}$ & T-Ed ${ }^{1}$ & Total & $\begin{array}{l}\mathrm{PA} \\
\%\end{array}$ & T-Ps ${ }^{2}$ \\
\hline $\begin{array}{l}\text { Education } \\
\text { (Education \& Psychology) }^{6}\end{array}$ & $\begin{array}{l}195 \\
(13\end{array}$ & $\begin{array}{c}89 \\
6)\end{array}$ & - & $\begin{array}{l}422 \\
(18\end{array}$ & $\begin{array}{c}60 \\
3)\end{array}$ & - & $\begin{array}{l}161 \\
(41\end{array}$ & 20 & 120 \\
\hline Psychology & 23 & 10 & 10 & 71 & 10 & 53 & 334 & 39 & - \\
\hline Psychiatry \& Neurology & 2 & 1 & - & 10 & 1 & - & 164 & 19 & - \\
\hline Business, Mgt, Economics & 14 & 6 & 4 & 77 & 11 & 64 & 46 & 5 & 44 \\
\hline Children & 9 & 4 & 2 & 23 & 3 & 14 & 22 & 3 & 12 \\
\hline Communication & 7 & 3 & 3 & 64 & 9 & 44 & 8 & 1 & 5 \\
\hline Crime \& Law & - & - & - & 10 & 1 & 7 & 21 & 2 & 21 \\
\hline Ethnic Concerns & 3 & 1 & 1 & 15 & 2 & 10 & 4 & 0 & 4 \\
\hline Humanities & 21 & 10 & 6 & 65 & 9 & 43 & 26 & 3 & 21 \\
\hline Linguistics & 12 & 6 & - & 82 & 12 & 41 & 8 & 1 & 7 \\
\hline \multicolumn{10}{|l|}{ Sciences: } \\
\hline -General \& Technology & 10 & 5 & - & 32 & 5 & 11 & 22 & 3 & 18 \\
\hline -Health Sciences & 13 & 6 & 8 & 30 & 4 & 21 & 142 & 16 & 124 \\
\hline -Math \& Statistics & 5 & 2 & 1 & 14 & 2 & 4 & 10 & 1 & 7 \\
\hline -Natural \& Physical Sci’s & 4 & 2 & 1 & 40 & 6 & 33 & 53 & 6 & 32 \\
\hline -Social Sciences & 8 & 4 & 1 & 78 & 11 & 57 & 94 & 11 & 65 \\
\hline Social Services & 7 & 3 & 7 & 13 & 2 & 11 & 21 & 2 & 18 \\
\hline Other & 2 & 1 & 1 & 5 & 1 & 3 & 10 & 1 & 6 \\
\hline
\end{tabular}

1) Total minus "Education" category.

2) Total minus "Psychology" category.

3) Percent of the $\mathbf{2 1 8}$ periodicals indexed by $E I$.

4) Percent of the 702 periodicals indexed by $C I J E$.

5) Percent of the 866 periodicals indexed by $P A$.

6) Figures also included in "Education" and "Psychology" categories. 
TABLE 2

The Number of Overlapping and Non-Overlapping Periodicals by Their Subject Orientation

\begin{tabular}{|c|c|c|c|c|c|c|c|}
\hline Subject & $\stackrel{\mathrm{a}}{\mathrm{EI}}$ & $\stackrel{b^{1}}{\text { EI/CIJE }}$ & CIJE & $\stackrel{\mathrm{b}^{1}}{\mathrm{CIJE} / \mathrm{PA}}$ & $\begin{array}{l}\text { PA } \\
\text { PA }\end{array}$ & $\begin{array}{c}\mathrm{b}^{1} \\
\mathrm{PA} / \mathrm{EI}\end{array}$ & EI/CIJE/PA \\
\hline $\begin{array}{l}\text { Education } \\
\text { (Education \& Psychology)² }\end{array}$ & $\underline{26}$ & $\begin{array}{l}166 \\
(13)\end{array}$ & $\begin{array}{l}226 \\
(1)\end{array}$ & $\begin{array}{c}91 \\
(17)\end{array}$ & $\begin{array}{c}67 \\
(24)\end{array}$ & $\begin{array}{c}64 \\
(13)\end{array}$ & $\begin{array}{l}61 \\
(13)\end{array}$ \\
\hline $\begin{array}{l}\text { Pauchtion \& Psycnology) } \\
\text { Psychology }\end{array}$ & 二 & 21 & 6 & 66 & 266 & 23 & $\begin{array}{l}(13) \\
21\end{array}$ \\
\hline Psychiatry \& Neurology & 1 & 1 & 2 & 8 & 156 & 1 & 1 \\
\hline Business, Mgt, Economics & 2 & 12 & $5 \overline{1}$ & 16 & 31 & 2 & $\tilde{2}$ \\
\hline Children & - & 9 & 9 & 11 & 11 & 6 & $\overline{6}$ \\
\hline $\begin{array}{l}\text { Communication } \\
\text { (Libraries) }^{3}\end{array}$ & - & 7 & $\begin{array}{l}57 \\
(26)\end{array}$ & 5 & 2 & 5 & 5 \\
\hline Crime \& Law & - & - & 10 & - & 21 & - & - \\
\hline Ethnic Concerns & - & 3 & 12 & 4 & 2 & 2 & 2 \\
\hline $\begin{array}{l}\text { Humanities } \\
\text { (Literature) }\end{array}$ & $\begin{array}{l}7 \\
(2)\end{array}$ & $\begin{array}{l}13 \\
(1)\end{array}$ & $\begin{array}{c}51 \\
(18)\end{array}$ & 3 & $\begin{array}{l}2 \overline{2} \\
(3)\end{array}$ & 3 & $\overline{2}$ \\
\hline $\begin{array}{l}\text { Linguistics } \\
\text { Sciences: }\end{array}$ & - & 12 & 67 & 6 & 2 & 3 & 3 \\
\hline - General \& Technology & - & 10 & 20 & 4 & 18 & 2 & 2 \\
\hline -Health Sciences & - & 12 & 8 & 19 & 122 & 10 & 9 \\
\hline -Math \& Statistics & - & 5 & 7 & 2 & 8 & - & - \\
\hline 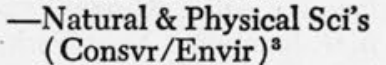 & 一 & 4 & $\begin{array}{l}35 \\
(21)\end{array}$ & 3 & $\begin{array}{l}50 \\
(1)\end{array}$ & 2 & 2 \\
\hline $\begin{array}{l}\text {-Social Sciences } \\
(\text { Sociology })^{3}\end{array}$ & 1 & $\begin{array}{c}8 \\
(3)\end{array}$ & $\begin{array}{l}54 \\
(24)\end{array}$ & $\begin{array}{l}19 \\
(14)\end{array}$ & $\begin{array}{r}75 \\
(44)\end{array}$ & $\begin{array}{l}3 \\
(3)\end{array}$ & $\begin{array}{l}3 \\
(3)\end{array}$ \\
\hline Social Services & - & 1 & 6 & 6 & 15 & - & - \\
\hline Other & - & 2 & 3 & 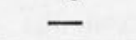 & 10 & - & - \\
\hline
\end{tabular}

1) Includes Column c.

2) Also counted in "Education" and "Psychology" categories.

3) Also counted in above category.

the health sciences. But beyond these areas, both indexes show an interest in every category.

Within the format of the data, educational psychology can only be narrowed to those titles classified by both "education" and "psychology" subject headings. According to Table 1, more of these can be found in $P A$, while Table 2 shows that all but one periodical can be found in PA (Table 2, CIJE "a" column). Therefore, without considering full or partial indexing as a factor, $P A$ should give access to virtually every educational psychology journal covered in these indexes.

The tables show that a mutual interest in each other's discipline does exist. However, by more than a two-to-one ratio (Table 1), PA appears to scan more periodicals in education than do $E I$ and CIJE for psychology. This includes an oddity in $P A$ 's unique cover- age (Table 2, PA "a" column) where sixty-seven educational journals are indexed by $P A$ and ignored by the educational indexes. Of these, twenty-six also concern psychology, but that still leaves forty-one. PA's international orientation accounts for twenty-nine foreign language journals, but again that leaves thirty-eight unique educational titles in psychology. Consequently, to scan all of the educational journals in these indexes, one must use all three in order to have access to those sixty-seven unique to $P A$ and the twenty-six found solely in EI. On the other hand, one must use CIJE for only six to eight unique titles in psychology and EI for one more in psychiatry.

\section{Summary and CoNClusions}

The intent of this study is to provide data that would give librarians a closer acquaintance with these indexes. The 
data are reduced to figures and tables which can be scanned according to specific interests. In sum, the overlap provides a series of comparisons which consider full and partial indexing, the growth and size of coverage, and the subject nature of the periodicals concerned. Comparison of the educational indexes reveals that the CIJE scans three times as many journals as does EI. However, it does not subsume EI completely, and the two differ on choices for full indexing. Each still has advantages for particular users.

In fact, for access to all of the educational periodicals covered, each of the indexes must be used. On the other hand, almost all psychology and psychiatry titles of the three are accessible through $P A$ alone. While $P A$ scans more periodicals in education than do $E I$ and CIJE in psychology, the two have a somewhat similar breadth of interests beyond educational psychology.

\section{REFERENCES}

1. Ulrich's International Periodicals Directory, 15th ed. (New York: Bowker, 1974).

2. Irregular Serials and Annuals: An International Directory, 3d ed. (New York: Bowker, 1974).

3. New Serial Titles (Washington, D.C.: Library of Congress).

4. Edwin B. Colburn, "The Wilson Periodical Indexes: A General Statement," $M L A$ Quarterly 30:92-95 (June 1969).

5. James Benson, "The Education Index," MLA Quarterly 30:118-23 (June 1969).

6. Arvid J. Burke and Mary A. Burke, Documentation in Education (New York: Teachers College Press, 1967), p.283-95.

7. Saul Herner, et al., Study of Periodicals and Serials in Education. Final Report (Bethesda, Md.: ERIC Document Reproduction Service, ED 017 747, 1968).

8. As noted in "Preface" to vol. 1, Current Index to Journals in Education (New York: CCM Information Corp., 1970), p.vi.

9. Alan Schorr, "Education Index and Current Index to Journals in Education: Do We Really Need Both?" Journal of Academic Librarianship 2:135-36 (July 1976).

10. Lawrence J. Perk, Review of CIJE and Education Index, "Education" section, in Serials Review 1:40 (Jan./June 1975).

11. Alan Schorr, "Education Index and Current Index to Journals in Education." 